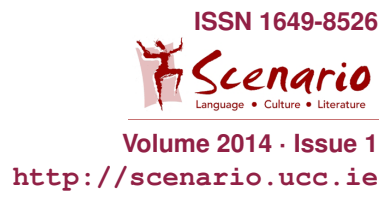

TaT - Texts around Theatre

\title{
The Gottfried Children
}

\section{Max Peter Ammann}

In this rubric we present various perspectives on theatre - historical and contemporary, intercultural and culture-specific, unexpectedly weird, unusually suspenseful, disturbedly gripping, fascinatingly enigmatic ...

With a sound reminiscent of military barracks, the desk lids fired upwards in salute as Gold Specs introduced Marc. The cisalpine school spirit already had a hold over the young Southerners. Three times, the principal gave exactly the same speech and ended with a compulsory suggestion: "I know, none of you will disappoint the new teacher."

Marc stood in front of his first students, his throat tight, and found himself unable to utter a word. He felt sorry for the boys and girls. Instead of a room with a big table, where talents and interests would emerge, where age levels would mingle, where students would assist each other, there were only oak benches, crammed closely together and bolted to the floor, the kind which force one to step in sideways. Everything was aligned towards the teacher; it was impossible to create a space free of hierarchy here.

From his coat pocket, Marc pulled Peter Petersen's "Jena Plan," ${ }^{11}$ as he had presented it to the New Education Fellowship in Locarno in 1927. He pressed it into the hand of the surprised director and requested a meeting with him and his colleagues.

"Let's at least take out the benches", Marc implored the representative of the Circolo Svizzero and his colleagues after a fruitless discussion, but he only saw alarm and mockery in their eyes. Alarm because of the prospect of improvising, which a teaching style with a flexible syllabus would require; mockery at the imposition of having to sit together with one's students, at the same table.

"Not a fool, that Petersen, but it's not in our budget," principal Trösch squirmed.

"A school bazaar with a raffle!" the young female teachers came to Marc's aid.

"Not now, not now, maybe around Christmas," Gold Specs waved the suggestion aside with a smile.

"Not at any time, not around Christmas either," Alma broke her silence. "Academic competence is what we need to foster here, not individual and social competence."

She had understood Petersen and her whole soul stood up against him. "We live in a dog-eat-dog world, young man. A fact which Petersen and his ilk don't give a damn about. I know that stuff: 'Man is born good, the environment spoils

\footnotetext{
${ }^{1}$ Peter Petersen (1884-1952) developed a concept for school reform which became known as the "Jena-Plan" and, for example, emphasized the importance of play in education.
} 
him.' Parents are spending a pretty penny to get our reality-oriented education, otherwise they would take their children to the public schools in Florence."

Marc hated her absoluteness more than her goal orientation. She is making us all into minions of the well-to-do, he thought. Most of all, he hated himself, because he kept silent.

The colleagues said nothing when he suggested a vote. Storybook democrats, all of them; Gessler's hat was the only thing missing to make them all kneel. Anger sent Marc's blood to his head. He wanted to seem indifferent, but his cheeks visibly burned red, and the respect which he couldn't bring himself to withhold from the old woman almost strangled him. Everything would stay the same. He was no Wilhelm Tell. ${ }^{2}$

... total failure on the first day ... back to the laws of gravity ... I'm supposed to clown ... swot French ... drill gymnastics ... have them cram from the textbook ... mathematics ... irregular verbs ... maybe it'll work with theater ... not soul carnival as in a monastery school ... not a carrot for a year of the school stick ... no, fictive reality ... students exchange their school behavior for characters in the play ... make the character's feelings, relationships, and conflicts their concern ... in French, obviously ... you can't play what you don't understand ... that takes months ... half a year ... maybe a whole year ... then there wouldn't be grades, there would just be the students themselves...

It worked.

Moving into the play sentence by sentence was not so much cumbersome as enthralling. Interest in the roles conquered the sluggish times. Vanity, the untiring human motor, pulled the cart out of each ditch. The question of space became a minor issue. At times it was the palestra, at times the classroom. At times the music room, at times the yard.

"Methodically rather interesting," opined the principal, "as long as the set syllabus for the year doesn't suffer."

Alma, who was of the most unyielding kind, let her monocle circle, unimpressed.

From: Max Peter Ammann (2011): Die Gottfriedkinder. Zürich: Rotpunktverlag, 309-311, (C) Rotpunktverlag

Translated by Silja Weber

\footnotetext{
${ }^{2}$ Wilhelm Tell is a drama written by Friedrich Schiller in 1804. Set in the period of the original foundation of the Old Swiss Confederacy in the early 14th century, the story focuses on the legendary folk hero Wilhelm Tell as part of the greater Swiss struggle for independence from the Habsburg Empire.
} 